\title{
ENDOGENOUS IRRIGATION: THE IMPACT OF CLIMATE CHANGE ON FARMERS IN AFRICA ${ }^{1}$
}

\author{
Pradeep Kurukulasuriya and Robert Mendelsohn ${ }^{2}$
}

\author{
World Bank Policy Research Working Paper 4278, July 2007
}

The Policy Research Working Paper Series disseminates the findings of work in progress to encourage the exchange of ideas about development issues. An objective of the series is to get the findings out quickly, even if the presentations are less than fully polished. The papers carry the names of the authors and should be cited accordingly. The findings, interpretations, and conclusions expressed in this paper are entirely those of the authors. They do not necessarily represent the view of the World Bank, its Executive Directors, or the countries they represent. Policy Research Working Papers are available online at http://econ.worldbank.org.

\footnotetext{
${ }^{1}$ An earlier version of this Working Paper was published as CEEPA Discussion Paper number 18.

${ }^{2}$ School of Forestry and Environmental Studies, Yale University, 230 Prospect St, New Haven, CT 06511, USA. E-mails: pradeep.kurukulasuriya@yale.edu; robert.mendelsohn@yale.edu

The authors would like to thank Rashid Hassan, James Benhin and Glwadys Gbetibouo, Centre for Environmental Economics and Policy in Africa (CEEPA), University of Pretoria, South Africa; Mbaye Diop and Isidor Sène, ISRA/LERG, Campus Universitaire de l'ESP, Senegal; Helmy Mohamed Eid, Samia El-Marsafawy and Samiha Ouda, Soil, Water \& Environment Research Institute (SWERI), Egypt; K Yerfi Fosu and Joseph Adu, Department of Agricultural Economics, University of Ghana; Suman Jain Mathematics and Statistics Department, University of Zambia; David Maddison, Department of Economics, University College London, UK; Ali Mahamadou and M Katiella, Faculty of Sciences, University of Abdou Moumouni of Niamey, Niger; Leopold Some and Mathieu Ouedraogo, Institut de l'Environnement et de Recherches Agricoles (INERA), Burkina Faso; and Ariel Dinar from the world Bank.

This paper was funded by the GEF and the World Bank. It is part of a larger study on the effect of climate change on agriculture in Africa, managed by the World Bank and coordinated by the Centre for Environmental Economics and Policy in Africa (CEEPA), University of Pretoria, South Africa.
} 


\section{SUMMARY}

Previous Ricardian analyses of agriculture have either omitted irrigation or treated irrigation as though it is exogenous. In practice, it is a choice by farmers that is sensitive to climate. This paper develops a choice model of irrigation in the context of a Ricardian model of cropland. We first examine how climate affects the decision to employ irrigation and then how climate affects the net revenues of dryland and irrigated land. This Ricardian 'selection' model, using a modified Heckman model, is then estimated across 8400 farmers in Africa. We explicitly model irrigation, but we control for the endogeneity of irrigation that plagues a recently suggested remedy.

We find that the choice of irrigation is sensitive to both temperature and precipitation. Simulating the welfare impacts of several climate scenarios, we demonstrate that a model which assumes irrigation is exogenous provides a biased estimate of the welfare effects of climate change. If dryland and irrigation are to be estimated separately in the Ricardian model, irrigation must be modeled endogenously.

The results also indicate that African agriculture is sensitive to climate change. Many farmers in Africa will experience net revenue losses from warming. We find that the elasticity of net revenue with respect to temperature is -0.82 for dryland farms. That is, a $10 \%$ increase in temperature will lead to a loss in net revenues per hectare, on average, of $8.2 \%$. Irrigated farms, on the other hand, are more resilient to temperature change and, on the margin, are likely to realize slight gains in productivity. However, any reduction in precipitation will be especially deleterious to dryland farmers, generally the poorest segment of the agriculture community. Dryland farms are sensitive to precipitation (elasticity of 0.28 ) whereas precipitation has virtually no effect on the net revenues of irrigated farms. As long as there is sufficient water, irrigation appears to buffer farms from precipitation. This is a consistent result across all the models tested in this paper.

The results indicate that irrigation is an effective adaptation against loss of rainfall and higher temperatures provided there is sufficient water available. This will be an effective remedy in select regions of Africa with water. However, for many regions there is no available surface water, so that warming scenarios with reduced rainfall are particularly deleterious. 


\section{TABLE OF CONTENTS}

$\begin{array}{ll}\text { Section } & \text { Page }\end{array}$

1 Introduction 4

2 Model 5

3 Empirical results 6

4 Climate change simulation 9

$\begin{array}{lll}5 & \text { Conclusions } & 10\end{array}$

$\begin{array}{ll}\text { References } & 11\end{array}$

Appendix A: Temperature normals (Sample means) 13

Appendix B: Precipitation normals (Sample means) 13 


\section{Introduction}

The Ricardian method for estimating the impacts of climate change on agriculture is a regression of land values (or net revenue) against climate and other exogenous characteristics (Mendelsohn et al. 1994). A consistent criticism that has been leveled at the first Ricardian study is that it did not properly take into account irrigation (Cline 1996; Darwin 1999; Schlenker et al. 2005). Adding a dummy variable for irrigation does not change the results (Mendelsohn \& Nordhaus 1999). However, in US samples, dryland and irrigated land do have different climate response functions (Mendelsohn \& Dinar 2003; Schlenker et al. 2005). Based on these results, Schlenker et al. (2005) argue that the welfare effects from climate change should be estimated separately for irrigated and dryland farms and added. However, this approach is problematic because it treats irrigation as though it is exogenous. The decision to irrigate is a choice and this choice is influenced by climate (Mendelsohn \& Dinar 2003). Further, there may be sample selection bias if we rely on farms that are observed to use dryland or irrigation.

In this paper, we develop a new Ricardian model that examines dryland and irrigated land separately but treats the choice of irrigation as endogenous. A variety of factors influence the decision on whether to irrigate. Surface flows, soil types, and subsidies all play a role in making this choice. But perhaps more importantly to climate analyses, the choice is sensitive to climate. Studies that assume irrigation is exogenous fail to take into account how irrigation will change as climate changes and therefore provide biased estimates of the impact of climate change. Moreover, these analyses of only irrigated farms and only dryland farms rely on self-selected samples, not random samples. Studies that fail to account for this nonrandomness in the modeling framework will be biased (Heckman 1979; Lee 1983). In Section 2 we develop a theoretical model that improves on past efforts to model irrigation with the Ricardian approach by explicitly addressing farmer choice and selection bias.

We tested this model empirically using a sample of over 8400 farmers from across 11 African countries. The results reveal that the choice of irrigation is endogenous. Farmers select irrigation rather than dryland to maximize profits. As temperatures warm or precipitation declines, farmers turn to irrigation to keep their farms viable. As long as there is a sufficient flow of water, irrigation is an important adaptation strategy.

We then used this empirical model to examine the welfare impacts of climate change on African agriculture. Using a mild and a severe climate scenario, we examined how irrigation and net revenues will be affected. We compared the results of our model with endogenous irrigation with a model that assumes irrigation is exogenous. We found evidence of selection bias but, more importantly, we found that treating irrigation as though it is exogenous leads to biased welfare estimates. The paper concludes by summarizing the results and discussing some policy implications. 


\section{Model}

The underlying theoretical structure of this model assumes that each farm maximizes profits:

$$
\max \Pi=P_{i} Q^{*}(X, E)-W X
$$

where $\Pi$ is profit, $P_{i}$ is output prices, $Q^{*}$ is output, $\mathrm{X}$ are chosen inputs, $\mathrm{E}$ is environmental factors such as climate and soils, and $\mathrm{W}$ is the price of inputs. In this paper, we assume that the amount of cropland is fixed, in order to focus on the issue of irrigation. ${ }^{3}$

Formally, we rely on an approach similar to the sample selection model for labor (Heckman 1979). However, there is an important difference. In the labor example, people who did not work had no observed income. In this model, farmers who choose not to irrigate still have observed income from dryland farming.

We assume that a farmer irrigates if irrigation is more profitable than dryland farming. In the first stage, we estimate a dichotomous choice model of irrigation, $Y$, where $Y=1$ is irrigation (1) and $Y=0$ is dryland farming:

$$
Y_{i}=\beta^{1} X+\mu_{1}
$$

In the second stage, we estimate a conditional profit function for each type of farming based on the available exogenous variables, $\mathrm{Z}$ :

$$
\begin{aligned}
& \prod_{i}=\gamma^{1} Z^{1}+\mu_{2} \text { if } \mathrm{Y}=1 \\
& \prod_{D}=\gamma^{D} Z^{D}+\mu_{3} \text { if } \mathrm{Y}=0
\end{aligned}
$$

where $Y_{1}$ is a latent variable explaining the choice of irrigation, $\Pi_{I}$ is the net profit of farms that have chosen irrigation, and $\Pi_{D}$ is the net profit of farms that have chosen dryland farming, $X$ is a $k$-vector of regressors, $Z^{I}$ is an $m$-vector of regressors for irrigation, $Z^{D}$ is an $m$-vector of regressors for dryland, and the error terms $U_{1}$ and $U_{2}$ and $U_{1}$ and $U_{3}$ are jointly normally distributed, independently of $X$ and $Z$, with zero expectations.

\footnotetext{
${ }^{3}$ Land uses themselves are influenced by climate and other variables (Mendelsohn et al. 1996). However, this topic is beyond the scope of this paper.
} 


$$
\begin{aligned}
& \mathrm{u}_{1} \sim \mathrm{N}(0,1) \\
& \mathrm{u}_{2} \sim \mathrm{N}\left(0, \sigma_{2}\right) \\
& \mathrm{u}_{3} \sim \mathrm{N}\left(0, \sigma_{3}\right) \\
& \operatorname{corr}\left(\mathrm{u}_{1}, \mathrm{u}_{2}\right)=\rho_{2} \\
& \operatorname{corr}\left(\mathrm{u}_{1}, \mathrm{u}_{3}\right)=\rho_{3}
\end{aligned}
$$

Irrigation is observed only if it is more profitable than dryland farming. Thus, the observed dependent variable $\mathrm{Y}$ is:

$$
\begin{aligned}
& Y=1 \text { if } \Pi_{I}>\Pi_{D} \\
& Y=0 \text { if } \Pi_{D}>\Pi_{I}
\end{aligned}
$$

When $\rho=0$, OLS (Ordinary Least Squares) regression provides unbiased estimates, but when $\rho \cong 0$ the OLS estimates are biased. We consequently employ the estimated Mills ratio from the selection model in both the irrigated and dryland conditional regressions in order to control for selection (Dubin \& McFadden 1984). We expect the signs on the coefficient of the estimated Mills ratio to be opposite in each regression. With the estimated Mills ratios, the selection model allows us to use information on whether farms irrigate or not to improve the estimates of the parameters in the regression model. That is, the selection model provides consistent, asymptotically efficient estimates for all parameters in the model (Dubin \& McFadden 1984).

\section{Empirical results}

The empirical analysis is based on a household survey conducted of 11 countries across Africa: Burkina Faso, Cameroon, Egypt, Ethiopia, Kenya, Ghana, Niger, Senegal, South Africa, Zambia and Zimbabwe (for more information about the entire study, see Dinar et al. 2006). It was difficult to collect land values in this setting. We consequently relied on measures of net revenue per hectare. Net revenue is defined as gross revenue minus the cost of transport, packaging and marketing, storage, post-harvest losses, hired labor (valued at the median market wage rate), light farm tools (such as files, axes, machetes, etc.), rental on heavy machinery (tractors, ploughs, threshers and others), fertilizer and pesticide. Median district prices from the survey were used for both input and crop prices. Household labor costs are not included as a cost in net revenues because it was not clear what value to assign to wages. We controlled for household labor by using household size as a proxy.

In each country, districts were chosen to get farms across a wide range of climate conditions in that country. In each chosen district, a random but clustered sample of farms was selected. The clustering helped to reduce survey expenses. The number of surveys in each country 
varied but a total of 9597 surveys were administered. After data cleaning, including removal of farms that did not grow crops, and surveys with field errors and missing information, the final number of useable surveys was 8463 . We conducted the analysis at the plot level of each farm as the dataset was sufficiently detailed to extract and utilize information about whether or not a particular plot (from a set of three) was irrigated or not. Each farm provided plot specific data on whether or not irrigation was used, crop production (including crop type, amount harvested, quantity sold, quantity consumed and amount of sales receipt) and crop costs (fertilizer, pesticide and seed data). Using this data, prices per crop and yields per hectare of farmland and cropland were estimated, as well as plot specific crop revenues and farm level gross and net revenues. Net revenue estimates are at the farm level because the input data, including labor (both hired and household) and machinery, were available only at that unit of measurement. It was not possible to allocate most inputs to specific plots as much of it was applied to several plots at a time. The dataset we used contains 1750 irrigated plots and 9183 dryland plots. The distribution of surveys - irrigated and dryland plots by country is shown in Table 1.

In this study, we relied on monthly temperature data collected from US Department of Defense satellites (Basist et al. 2001). This set of polar orbiting satellites obtain measurements at a given location on earth at $6 \mathrm{am}$ and $6 \mathrm{pm}$ every day. The satellites are equipped with sensors that measure surface temperature by detecting microwaves that pass through clouds (Weng \& Grody 1998). The monthly precipitation data comes from the Africa Rainfall and Temperature Evaluation System (ARTES) (World Bank 2003). This dataset, created by the National Oceanic and Atmospheric Association's Climate Prediction Center, is based on ground station measurements of precipitation over the period 1948-2001. The average temperatures and precipitation for each country in the sample are shown in Appendices A and B. Note that there is a wide range of climates across the 11 countries in the sample.

It is not possible to use every month of climate in a Ricardian regression because of the high correlation between one month and the next. Consequently we must cluster the monthly data into seasons. However, it is not self-evident how to cluster monthly temperatures into a limited set of seasonal measurements. We explored several ways of defining three-month average seasons, starting with November, December, and January for winter. Comparing the results, we found that defining winter in the northern hemisphere as the average of November, December, and January provided the most robust results for Africa. This assumption in turn implies that the next three months would be spring, the three months after that would be summer, and August, September and October would be fall (in the north). These seasonal definitions were chosen because they provided the best fit with the data and reflected the mid-point for key rainy seasons in the sample. We adjusted for the fact that seasons in the southern and northern hemispheres occur at exactly the opposite months of the year.

Soil data was obtained from FAO (2003). The FAO data provides information about the major and minor soils in each location. Data concerning the hydrology was predicted from a hydrological model for Africa (Strzepek \& McCluskey 2006). The model calculated the water flow through each district in the surveyed countries. Data on elevation at the centroid of each district was obtained through GIS manipulation using data from the United States Geological Survey (USGS, 2004). The USGS data are derived from a global digital elevation model with a horizontal grid spacing of 30 arc seconds (approximately one kilometer). 
During pre-testing of the survey instrument ${ }^{4}$, it was determined that some African farmers cultivated at least two plots of land. Subsequently, the survey data collected crop data, including production quantities, amount sold, and sale receipts from crops for the largest single plot of cultivated land (referred to hereafter as the main plot) and all others (referred to as the secondary plot). In the following analysis we therefore contend with two plots.

In the first stage of the analysis, we estimated a probit model of whether to irrigate or not (Table 2). We relied on the 10880 plots (out of a total of 10933) for which we have complete information for the regression. The explanatory variables in the first stage included seasonal climate variables, various soils, and flow (millions of $\mathrm{m}^{3}$ ). We included only the linear climate variables in the first stage. We tested the inclusion of quadratic climate variables but found the linear model to be more reliable. ( $\log$ pseudolikelihood $=-2340.59$ and r-squared 0.51 versus -2187.4434 and 0.54 , respectively, for the quadratic probit model.) The Chow test for determining the null hypothesis that the estimated parameters are jointly the same is rejected $\left(\mathrm{chi}^{2}(30)=3967.66\right.$; Prob $\left.>\mathrm{chi}^{2}=0.0000\right)$. The coefficients (which are highly significant) suggest that the probability of adoption of irrigation increases with higher temperatures and precipitation in each season except in spring. The reported standard errors in the paper are based on the Huber-White estimator of variance which are robust against many types of misspecification of the model (Heltberg \& Tarp 2002). The annual marginal effects, which are more informative of the decision to irrigate or not, reflected in the probability response functions of choosing irrigation given delta temperature increments (holding all other variables constant), reflect the current irrigation landscape in Africa. The probability of adoption of irrigation increases in regions with lower temperatures (for example Egypt and South Africa), while it decreases in warmer regions. Irrigation in cooler regions is more profitable because it requires less water and the crops are more productive. Similarly, in regions of higher precipitation or available flow, the probability of adopting irrigation decreases. Irrigation is less profitable in wetter locations because the fixed cost of irrigation remains the same but the net increment to production declines.

In the probit model, we controlled for water flow by including the log transformation of a long run average (30 years) of estimated mean flow. The coefficient on this variable is positive and significant. In the selection model, we also controlled for soils. The soil variables reflect the proportion of a district with a particular soil type. The inclusion of certain soils specific to a particular region or district results in the model not being full rank (thereby making the interpretation of the statistical significance of the coefficients unreliable). As a result, we included only those soils that are jointly significant for both irrigated and dryland farms.

We then turned to estimating the second stage model of net revenue conditional on type of farm (Table 3, endogenous columns). We used the coefficients of the probit model to estimate the Mills ratio. Following the standard Heckman model, we included the Mills ratio as an additional explanatory variable to control for self-selection bias in the second stage OLS model (Dubin \& McFadden 1984). We examined two sets of second stage OLS models: one for dryland and one for irrigated land. The coefficient on the estimated Mills ratio is significant in the dryland regression and negative as anticipated but not significant in the irrigated model. We tested several control variables in each regression (including gender, education and whether the head of the household was a full time farmer), but dropped them because they were not significant.

\footnotetext{
${ }^{4}$ Available on request from the authors.
} 
A comparison of the OLS coefficients in Table 3 confirms our hypothesis that irrigated and dryland farms are different. The log of size of household has a positive effect on net revenue per hectare for both irrigated and dryland farms. Household size is logged because productivity per worker is expected to fall as households become too large. The coefficient of the log of elevation is negative and significant in the dryland equation but it is not significant in the irrigated model. In addition, our findings lend support to the controversial but often observed inverse relationship between farm size and productivity (Sen 1962). Controlling for labor, machinery and other farm inputs, including irrigation and technology, small farms have higher net revenues per hectare than large farms. In our study, net revenue per hectare may be higher because farmers devote more household labor per hectare on smaller farms. We also included a dummy variable that denotes whether or not a farm has electricity. It is clear that electrified farms outperform farms that do not have electricity in both the irrigated and dryland models. Electrification might directly enhance productivity and earnings or it may simply be a proxy for farms that are closer to markets or more modern.

The second stage regressions give an important insight into the climate sensitivity of farms. The results clearly show that dryland and irrigated farms are both sensitive to climate. Evaluating the marginal impact of temperature and precipitation at the mean climate for the sample reveals many significant seasonal impacts (Table 4a,b). In most seasons (except for winter temperature and winter and spring precipitation), the signs of the coefficients for both types of farms are in the same direction. However, the marginal effects of changes in temperature are not the same across seasons. In spring and fall, the marginal temperature effect is negative whereas in summer and winter it is positive.

These offsetting seasonal effects make annual impacts more ambiguous. The annual marginal impacts of temperature and precipitation are shown in Table 5. The magnitudes of the annual temperature effects for dryland and irrigated farms are different. The resulting elasticity of net revenue with respect to temperature is -0.81 and 0.31 for dryland and irrigated farms respectively. The precipitation results for dryland and irrigated land are also quite different. Dryland farms are sensitive to precipitation (elasticity of 0.28 ) whereas precipitation has virtually no effect on the net revenues of irrigated farms. As long as there is sufficient water, irrigation appears to buffer farms from insufficient precipitation.

In addition to the second stage regressions in Table 3, we also estimated a pair of regressions that treat irrigation as exogenous (Schlenker et al. 2005). The difference is that the first two columns also include the Mills ratio (i.e., first two columns-endogenous adjust for sample selection bias). Although the Mills ratio coefficient is significant in the dryland regression, it is not significant in the irrigated regression. Further, the climate coefficients in the two dryland and two irrigated regressions are quite similar. Sample selection bias does not appear to be an important problem in this dataset. Figures 1 and 2 plot the resultant response functions from the selection model as well as the second stage conditional models for dryland and irrigated farms by varying temperature and precipitation respectively.

\section{Climate change simulation}

In this section, we calculate the welfare effect of changing climate. We compare the welfare results from our endogenous modeling approach with the welfare results from the exogenous model of irrigation (Schlenker et al. 2005). Note that with the exogenous model of irrigation, 
it is assumed that climate change has no effect on the probability of irrigation. The endogenous model allows this probability to change with the climate scenario.

We examined four simple scenarios to illustrate the importance of modeling irrigation correctly. The scenarios assume a uniform change in either temperature or precipitation across Africa. We examined two temperature changes of $2.5^{\circ} \mathrm{C}$ and $5.0^{\circ} \mathrm{C}$ warming and a $+20 \%$ and a $-20 \%$ change in precipitation. In Table 6 , we present the results of each scenario. First, we demonstrated that the different climate change scenarios change the fraction of farms that are irrigated. Second, we showed that the welfare estimates using a model that addresses endogeneity (referred herein as the 'endogenous model') and the model that assumes that irrigation is exogenous when it is not (referred to as the 'exogenous model') are quite different. Our endogenous model indicates the overall changes in welfare from a 2.5 and 5 degree increase in temperature are $-8 \%$ and $-14 \%$ respectively. The exogenous model overestimates the welfare losses in both cases. Our endogenous model predicts that a $20 \%$ decrease in precipitation reduces overall welfare by $21 \%$ while a $20 \%$ increase in precipitation increases welfare by $18 \%$. The exogenous model underestimates both the damages and benefits of these two scenarios respectively. By failing to take into account how farmers change their irrigation decision as climate changes, the exogenous model leads to biased welfare estimates.

\section{Conclusions}

This paper provided an improved modeling framework for the Ricardian method in analyzing the effect of irrigation on farm performance. We explicitly modeled irrigation as recommended (Cline 1996; Darwin 1999; Schlenker et al. 2005), but we controlled for the endogeneity of irrigation that plagues a recently suggested remedy (Schlenker et al. 2005). Our results indicate that treating irrigation as exogenous leads to biased welfare estimates from climate change. If dryland and irrigation are to be estimated separately in the Ricardian model, irrigation must be modeled endogenously.

The results also indicate that African agriculture is sensitive to climate change. Many farmers in Africa will experience net revenue losses from warming. Any reduction in precipitation will be especially deleterious to dryland farmers, generally the poorest segment of the agriculture community. Irrigation is an effective adaptation against loss of rainfall and higher temperatures provided there is sufficient water available. This will be an effective remedy in select regions of Africa with water (FAO 1997). However, for many regions, there is no available surface water, so that warming scenarios with reduced rainfall are particularly deleterious. On the other hand, mild warming scenarios with increased rainfall may not be harmful at all. 


\section{REFERENCES}

Basist A et al., 2001. Using the Special Sensor Microwave Imager to monitor surface wetness. Journal of Hydrometeorology 2: 297-308.

Cline WR, 1996. The impact of global warming on agriculture: Comment. American Economic Review 86: 1309-1312.

Darwin R, 1999. The impacts of global warming on agriculture: A Ricardian analysis: Comment. American Economic Review 89: 1049-1052.

Dubin JA \& McFadden DL, 1984. An econometric analysis of residential electric appliance holdings and consumption. Econometrica 52(2): 345-362.

FAO (Food and Agriculture Organization), 1997. Irrigation potential in Africa: A basin approach. FAO Land and Water Bulletin, 4, FAO Land and Water Development Division, Rome.

FAO (Food and Agriculture Organization), 2003. The digital soil map of the world: Version 3.6 (January), Rome, Italy.

Heckman JJ, 1979. Sample selection bias as a specification error. Econometrica 47: 153-161.

Heltberg R \& Tarp F, 2002. Agricultural supply response and poverty in Mozambique. Food Policy 27: 103-124.

Kurukulasuriya P \& Mendelsohn R, 2005. A regional analysis of the impact of climate change on African agriculture, Mimeo, Yale University.

Lee LF, 1983. Generalized econometric models with selectivity. Econometrica 51: 507-512.

Mendelsohn R \& Dinar A, 2003. Climate, water, and agriculture. Land Economics 79(3): $328-341$.

Mendelsohn R \& Nordhaus W, 1996. The impact of global warming on agriculture: Reply. American Economic Review 86: 1312-1315.

Mendelsohn R \& Nordhaus W, 1999. The impact of global warming on agriculture: Reply to Darwin. American Economic Review 89: 1053-1055.

Mendelsohn R, Nordhaus W \& Shaw D, 1994. The impact of global warming on agriculture: A Ricardian analysis. American Economic Review 84: 753-771.

Mendelsohn R, Nordhaus W \& Shaw D, 1996. Climate impacts on aggregate farm values: Accounting for adaptation. Agriculture and Forest Meteorology 80: 55-67.

Schlenker W, Hanemann M \& Fischer A, 2005. Will US agriculture really benefit from global warming? Accounting for irrigation in the hedonic approach. American Economic Review, 95(1): 395-406.

Sen AK, 1962. An aspect of Indian agriculture. Economics Weekly Annual Number: 243-66. 
Strzepek K \& McCluskey A, 2006. District level hydroclimatic time series and scenario analysis to assess the impacts of climate change on regional water resources and agriculture in Africa. CEEPA Discussion Paper No 13, Centre for Environmental Economics and Policy in Africa, University of Pretoria.

USGS (US Geological Survey), 2004. Global 30 Arc Second Elevation Data, USGS National Mapping Division, EROS Data Centre. (These data files are downloadable from http://edcdaac.usgs.gov/gtopo30/gtopo30.asp)

Weng F \& Grody N, 1998. Physical retrieval of land surface temperature using the Special Sensor Microwave Imager. Journal of Geophysical Research 103: 8839-8848.

World Bank, 2003. Africa rainfall and temperature evaluation system (ARTES). World Bank, Washington DC. 
APPENDICES

Appendix A: Temperature normals (Sample means)

\begin{tabular}{lcccc}
\hline country & winter & spring & summer & fall \\
\hline burkinafaso & 23.55 & 28.34 & 28.87 & 24.48 \\
cameroon & 19.38 & 21.38 & 19.97 & 18.87 \\
egypt & 11.67 & 13.17 & 24.11 & 23.38 \\
ethiopia & 18.64 & 21.53 & 19.71 & 18.07 \\
ghana & 21.79 & 24.81 & 22.63 & 21.16 \\
kenya & 18.75 & 19.72 & 18.36 & 19.12 \\
niger & 26.28 & 30.83 & 33.91 & 29.18 \\
senegal & 24.54 & 29.13 & 31.53 & 26.67 \\
south africa & 11.53 & 15.47 & 20.73 & 19.37 \\
zambia & 16.69 & 21.72 & 21.09 & 19.58 \\
zimbabwe & 16.58 & 21.29 & 22.49 & 20.63 \\
total & 19.82 & $\mathbf{2 3 . 3 5}$ & $\mathbf{2 4 . 5 2}$ & $\mathbf{2 2 . 2 3}$ \\
\hline
\end{tabular}

Appendix B: Precipitation normals (Sample means)

\begin{tabular}{lcccc}
\hline country & winter & spring & summer & fall \\
\hline burkinafaso & 2.6 & 15.83 & 113.78 & 133.12 \\
cameroon & 60.25 & 101.94 & 185.08 & 228.55 \\
egypt & 12.81 & 7.02 & 2.3 & 3.51 \\
ethiopia & 19.42 & 49.21 & 123.71 & 117.51 \\
ghana & 30.87 & 59.66 & 112.4 & 111.74 \\
kenya & 88.38 & 103.02 & 84.31 & 59.95 \\
niger & 0.75 & 3.15 & 64.05 & 70.55 \\
senegal & 2.23 & 1.05 & 47.93 & 112.72 \\
south africa & 31.79 & 54.96 & 86.38 & 68.79 \\
zambia & 48.26 & 57.7 & 108.58 & 100.67 \\
zimbabwe & 7.54 & 15.4 & 138.75 & 89.98 \\
total & $\mathbf{2 5 . 8 5}$ & $\mathbf{3 9 . 8 3}$ & 96.05 & 102.4 \\
\hline
\end{tabular}


Table 1: Sample of farms

\begin{tabular}{lrrr}
\hline Country & $\begin{array}{c}\text { No. of } \\
\text { plots }\end{array}$ & $\begin{array}{c}\text { Irrigated } \\
\text { plots }\end{array}$ & $\begin{array}{c}\text { Dryland } \\
\text { plots }\end{array}$ \\
\hline Burkina Faso & 1141 & 59 & 1082 \\
Cameroon & 1013 & 145 & 868 \\
Egypt & 1030 & 1030 & 0 \\
Ethiopia & 932 & 67 & 865 \\
Ghana & 1210 & 49 & 1161 \\
Kenya & 862 & 95 & 767 \\
Niger & 1133 & 52 & 1081 \\
Senegal & 1362 & 34 & 1328 \\
South Africa & 283 & 83 & 200 \\
Zambia & 1009 & 13 & 996 \\
Zimbabwe & 958 & 123 & 835 \\
\hline Total & $\mathbf{1 0 9 3 3}$ & $\mathbf{1 7 5 0}$ & $\mathbf{9 1 8 3}$ \\
\hline
\end{tabular}


Table 2: Probit model of whether to irrigate

\begin{tabular}{|c|c|}
\hline Dependent variable & $\begin{array}{c}\text { Irrigated } \\
(\mathbf{1} / \mathbf{0})\end{array}$ \\
\hline Temperature winter & $\begin{array}{c}0.19^{* * *} \\
(6.53)\end{array}$ \\
\hline Temperature spring & $\begin{array}{c}-0.46^{* * *} \\
(17.15)\end{array}$ \\
\hline Temperature summer & $\begin{array}{c}0.14 * * * \\
(3.86)\end{array}$ \\
\hline Temperature fall & $\begin{array}{c}0.15^{* * *} \\
(3.56)\end{array}$ \\
\hline Precipitation winter & $\begin{array}{c}0.01 * * * \\
(3.23)\end{array}$ \\
\hline Precipitation spring & $\begin{array}{c}-0.01^{* * *} \\
(3.54)\end{array}$ \\
\hline Precipitation summer & $\begin{array}{c}0.005 * * * \\
(5.07)\end{array}$ \\
\hline Precipitation fall & $\begin{array}{l}0.002 * \\
(2.45)\end{array}$ \\
\hline $\log ($ mean flow- m3) & $\begin{array}{c}0.06^{* * *} \\
(8.17)\end{array}$ \\
\hline Chromic cambisols & $-1.16^{*}$ \\
\hline Medium, steep & $(2.41)$ \\
\hline Eutric cambisols & -2.91 \\
\hline Fine, medium & $(0.59)$ \\
\hline Vertic cambisols & $1.13 * *$ \\
\hline Fine & $(2.62)$ \\
\hline Vertic cambisols & 4.68 \\
\hline Medium, undulating & $(1.88)$ \\
\hline Rhodic ferralsols & 1.27 \\
\hline Fine, hilly, steep & $(.61)$ \\
\hline Lithosols & -4.86 \\
\hline Coarse, medium, fine, steep & $(1.49)$ \\
\hline Lithosols/Eutric gleysols & $10.58 * *$ \\
\hline Hilly & $(3.69)$ \\
\hline Chromic luvisols & 0.57 \\
\hline Medium,undulating, hilly & $(1.82)$ \\
\hline
\end{tabular}


Table 2 (continued):

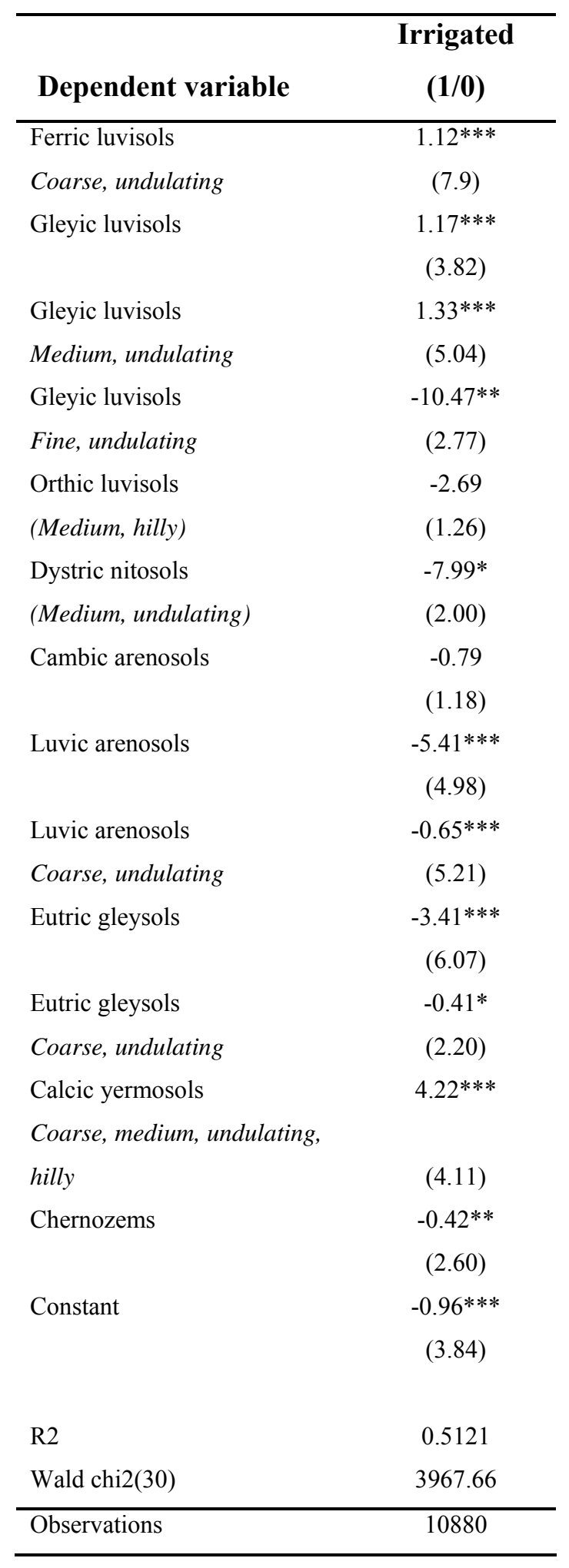

${ }^{*} \mathrm{p}<0.05 ; * * \mathrm{p}<0.01 ; * * * \mathrm{p}<0.001$ 
Table 3: Net revenue regressions

\begin{tabular}{|c|c|c|c|c|}
\hline Dependent variable & $\begin{array}{c}\text { Endogenous } \\
\text { Net rev/ha } \\
\text { (dryland farm) }\end{array}$ & $\begin{array}{c}\text { Endogenous } \\
\text { Net rev/ha } \\
\text { (irrigated } \\
\text { farm) }\end{array}$ & $\begin{array}{c}\text { Exogenous } \\
\text { Net rev/ha } \\
\text { (dryland } \\
\text { farm) }\end{array}$ & $\begin{array}{c}\text { Exogenous } \\
\text { Net rev/ha } \\
\text { (irrigated } \\
\text { farm) }\end{array}$ \\
\hline Temperature winter & $\begin{array}{c}-120.61^{*} \\
(2.33)\end{array}$ & $\begin{array}{c}374.41 * \\
(2.34)\end{array}$ & $\begin{array}{c}-124.8103^{*} \\
(2.41)\end{array}$ & $\begin{array}{c}380.9378^{*} \\
(2.4)\end{array}$ \\
\hline Temperature winter sq & $\begin{array}{c}4.58 * * * \\
(3.39)\end{array}$ & $\begin{array}{l}-6.79 \\
(1.53)\end{array}$ & $\begin{array}{c}4.79 * * * \\
(3.54)\end{array}$ & $\begin{array}{l}-5.83 \\
(1.31)\end{array}$ \\
\hline Temperature spring & $\begin{array}{c}-18.86 \\
(0.2)\end{array}$ & $\begin{array}{c}-284.49 \\
(1.57)\end{array}$ & $\begin{array}{l}-19.97 \\
(0.22)\end{array}$ & $\begin{array}{c}-328.38 \\
(1.91)\end{array}$ \\
\hline Temperature spring sq & $\begin{array}{l}-1.88 \\
(0.98)\end{array}$ & $\begin{array}{l}2.53 \\
(0.6)\end{array}$ & $\begin{array}{l}-2.02 \\
(1.05)\end{array}$ & $\begin{array}{l}1.69 \\
(0.4)\end{array}$ \\
\hline Temperature summer & $\begin{array}{c}205.86^{* * * *} \\
(2.95)\end{array}$ & $\begin{array}{c}1180.58^{* * * *} \\
(4.28)\end{array}$ & $\begin{array}{c}212.32 * * \\
(3.06)\end{array}$ & $\begin{array}{c}1233.61 * * * \\
(4.66)\end{array}$ \\
\hline Temperature summer sq & $\begin{array}{c}-2.6 \\
(1.95)\end{array}$ & $\begin{array}{c}-18.27 * * * \\
(3.81)\end{array}$ & $\begin{array}{l}-2.73 * \\
(2.05)\end{array}$ & $\begin{array}{c}-18.96^{* * *} \\
(4.06)\end{array}$ \\
\hline Temperature fall & $\begin{array}{l}-58.81 \\
(1.04)\end{array}$ & $\begin{array}{c}-1592.37 * * * \\
(4.11)\end{array}$ & $\begin{array}{l}-61.66 \\
(1.09)\end{array}$ & $\begin{array}{c}-1592.27 * * * \\
(4.09)\end{array}$ \\
\hline Temperature fall sq & $\begin{array}{c}0.26^{* * * *} \\
(0.22)\end{array}$ & $\begin{array}{c}29.27 * * * \\
(3.78)\end{array}$ & $\begin{array}{c}0.41 \\
(0.34)\end{array}$ & $\begin{array}{c}29.72 * * * \\
(3.85)\end{array}$ \\
\hline Precipitation winter & $\begin{array}{c}-4.37 * * * \\
(3.71)\end{array}$ & $\begin{array}{c}12.13^{* * * *} \\
(1.86)\end{array}$ & $\begin{array}{c}-4.33 * * * \\
(3.67)\end{array}$ & $\begin{array}{l}12.13 \\
(1.86)\end{array}$ \\
\hline Precipitation winter sq & $\begin{array}{c}0.03 * * * \\
(4.54)\end{array}$ & $\begin{array}{l}0.003 \\
(0.08)\end{array}$ & $\begin{array}{l}.03 * * * \\
(4.61)\end{array}$ & $\begin{array}{l}0.005 \\
(0.11)\end{array}$ \\
\hline Precipitation spring & $\begin{array}{c}4.09 * * * \\
(3.64)\end{array}$ & $\begin{array}{c}-12.59 * \\
(2.18)\end{array}$ & $\begin{array}{c}4.01 * * * \\
(3.56)\end{array}$ & $\begin{array}{l}-13.1^{*} \\
(2.26)\end{array}$ \\
\hline Precipitation spring sq & $\begin{array}{l}-0.01 \\
(1.43)\end{array}$ & $\begin{array}{c}0.01 \\
(0.13)\end{array}$ & $\begin{array}{l}-0.01 \\
(1.45)\end{array}$ & $\begin{array}{c}0.01 \\
(0.17)\end{array}$ \\
\hline Precipitation summer & $\begin{array}{c}4.56 * * * \\
(6.47)\end{array}$ & $\begin{array}{c}21.65 * * * \\
(4.45)\end{array}$ & $\begin{array}{c}4.67 * * * \\
(6.6)\end{array}$ & $\begin{array}{c}22.88^{* * *} \\
(4.9)\end{array}$ \\
\hline Precipitation summer sq & $\begin{array}{c}-0.02 * * * \\
(5.35)\end{array}$ & $\begin{array}{c}-0.09 * * * \\
(4.84)\end{array}$ & $\begin{array}{c}-.02 * * * \\
(5.35)\end{array}$ & $\begin{array}{c}-.09 * * * \\
(4.91)\end{array}$ \\
\hline Precipitation fall & $\begin{array}{l}-1.24 \\
(1.94)\end{array}$ & $\begin{array}{c}-21.36^{* * *} \\
(4.58)\end{array}$ & $\begin{array}{l}-1.28^{*} \\
(2.01)\end{array}$ & $\begin{array}{c}-22.18^{* * *} \\
(4.82)\end{array}$ \\
\hline Precipitation fall sq & $\begin{array}{c}0.01 * * * \\
(5.01)\end{array}$ & $\begin{array}{c}0.09 * * * \\
(5.54)\end{array}$ & $\begin{array}{l}.01 * * * \\
(5.02)\end{array}$ & $\begin{array}{l}.09 * * * \\
(5.62)\end{array}$ \\
\hline
\end{tabular}


Table 3 (continued):

\begin{tabular}{|c|c|c|c|c|}
\hline Dependent variable & $\begin{array}{c}\text { Endogenous } \\
\text { Net rev/ha } \\
\text { (dryland farm) }\end{array}$ & $\begin{array}{c}\text { Endogenous } \\
\text { Net rev/ha } \\
\text { (irrigated } \\
\text { farm) }\end{array}$ & $\begin{array}{c}\text { Exogenous } \\
\text { Net rev/ha } \\
\text { (dryland } \\
\text { farm) }\end{array}$ & $\begin{array}{c}\text { Exogenous } \\
\text { Net rev/ha } \\
\text { (irrigated } \\
\text { farm) }\end{array}$ \\
\hline Chromic cambisols & $-411.09 * *$ & -407.91 & $-439.31 * * *$ & -559.54 \\
\hline Medium, steep & $(3.12)$ & $(0.45)$ & (3.34) & $(0.63)$ \\
\hline Eutric cambisols & $5245.34^{*}$ & 17791.66 & $5130.45 *$ & 16604.16 \\
\hline Fine, medium & $(2.35)$ & $(1.6)$ & $(2.31)$ & $(1.5)$ \\
\hline Vertic cambisols & -103.68 & $839.82 * * *$ & -85.62 & $1053.52 * * *$ \\
\hline Fine & $(1.58)$ & $(3.75)$ & $(1.3)$ & $(5.68)$ \\
\hline Rhodic ferralsols & $-1868.95 * *$ & -330.48 & $-1857.75^{*}$ & -62.59 \\
\hline Fine, hilly, steep & $(2.99)$ & $(0.08)$ & $(2.98)$ & $(0.02)$ \\
\hline Lithosols & 545.78 & $16032.28 * * *$ & 438.83 & $15186.80 * * *$ \\
\hline $\begin{array}{l}\text { Coarse, medium, fine, } \\
\text { steep }\end{array}$ & $(0.48)$ & $(9.61)$ & $(0.39)$ & $(10.04)$ \\
\hline Chromic luvisols & $-670.35 * * *$ & $3023.22 *$ & $-662.76^{* * *}$ & $3069.53 *$ \\
\hline Medium,undulating, hilly & $(6.63)$ & $(2.51)$ & $(6.54)$ & $(2.56)$ \\
\hline Ferric luvisols & $-108.7 * * *$ & -112.59 & $-81.45^{* * *}$ & 91.64 \\
\hline Coarse, undulating & $(5.55)$ & $(0.62)$ & $(4.52)$ & $(0.73)$ \\
\hline Gleyic luvisols & $\begin{array}{c}-181.87^{* * * *} \\
(4.38)\end{array}$ & $\begin{array}{c}-788.35^{*} \\
(2.56)\end{array}$ & $\begin{array}{c}-147.84 * * * \\
(3.62)\end{array}$ & $\begin{array}{c}-382.29 * \\
(2.52)\end{array}$ \\
\hline Gleyic luvisols & $655.41 * * *$ & -289.07 & $681.85705^{* * *}$ & -46.39 \\
\hline Medium, undulating & $(4.43)$ & $(1.2)$ & $(4.61)$ & $(0.25)$ \\
\hline Gleyic luvisols & $1010.34 * *$ & -596.26 & $997.31532 * *$ & -66.85736 \\
\hline Fine, undulating & $(3.25)$ & $(1.35)$ & $(3.27)$ & $(0.25)$ \\
\hline $\begin{array}{l}\text { Orthic luvisols } \\
\text { (Medium, hilly) }\end{array}$ & $\begin{array}{c}-791.89 \\
(1.26)\end{array}$ & $\begin{array}{c}-3745.32 * \\
(2.17)\end{array}$ & $\begin{array}{c}-844.16545 \\
(1.35)\end{array}$ & $\begin{array}{c}-4296.4641 * * \\
(2.64)\end{array}$ \\
\hline Chernozems & $\begin{array}{c}177.49 * * * \\
(4.32)\end{array}$ & $\begin{array}{c}-219.62 \\
(0.69)\end{array}$ & $\begin{array}{c}183.69602 * * * \\
(4.48)\end{array}$ & $\begin{array}{c}-149.10838 \\
(0.48)\end{array}$ \\
\hline Household electrified & & & & \\
\hline$(1 / 0)$ & $\begin{array}{c}119.4^{* * * *} \\
(7.44)\end{array}$ & $\begin{array}{c}302.13 * * * \\
(3.43)\end{array}$ & $\begin{array}{c}120.62 * * * \\
(7.55)\end{array}$ & $\begin{array}{c}304.11^{* * *} \\
(3.48)\end{array}$ \\
\hline Log (household size) & $\begin{array}{c}29.81 * * \\
(2.72)\end{array}$ & $\begin{array}{c}124.85 * \\
(2.03)\end{array}$ & $\begin{array}{c}30.74 * * \\
(2.81)\end{array}$ & $\begin{array}{l}116.90 \\
(1.91)\end{array}$ \\
\hline
\end{tabular}


Table 3 (continued):

\begin{tabular}{|c|c|c|c|c|}
\hline Dependent variable & $\begin{array}{c}\text { Endogenous } \\
\text { Net rev/ha } \\
\text { (dryland farm) }\end{array}$ & $\begin{array}{c}\text { Endogenous } \\
\text { Net rev/ha } \\
\text { (irrigated } \\
\text { farm) }\end{array}$ & $\begin{array}{c}\text { Exogenous } \\
\text { Net rev/ha } \\
\text { (dryland } \\
\text { farm) }\end{array}$ & $\begin{array}{c}\text { Exogenous } \\
\text { Net rev/ha } \\
\text { (irrigated } \\
\text { farm) }\end{array}$ \\
\hline Area of plot & $\begin{array}{c}-0.6^{* * *} \\
(3.95)\end{array}$ & $\begin{array}{l}-0.06^{*} \\
(2.28)\end{array}$ & $\begin{array}{c}-.61 * * * \\
(4.00)\end{array}$ & $\begin{array}{l}-.06^{*} \\
(2.14)\end{array}$ \\
\hline Area of plot sq & $\begin{array}{c}.0000965^{* *} \\
(2.79)\end{array}$ & $\begin{array}{c}7.237 \mathrm{e}-07 * \\
(2.2)\end{array}$ & $\begin{array}{c}.000097 * * \\
(2.81)\end{array}$ & $\begin{array}{c}7.278 \mathrm{e}-07 * \\
(2.08)\end{array}$ \\
\hline Log (elevation - meters) & $\begin{array}{c}-16.85^{*} \\
(2.31)\end{array}$ & $\begin{array}{l}63.87 \\
(1.89)\end{array}$ & $\begin{array}{c}-15.64 * \\
(2.15)\end{array}$ & $\begin{array}{l}62.85 \\
(1.86)\end{array}$ \\
\hline Inverse Mills ratio & $\begin{array}{c}-19.22 * * * \\
(4.82)\end{array}$ & $\begin{array}{c}-256.95 \\
(1.53)\end{array}$ & & \\
\hline Constant & $\begin{array}{c}-106.24 \\
(0.18)\end{array}$ & $\begin{array}{c}4169.51^{*} \\
(2.07)\end{array}$ & $\begin{array}{c}-143.72 \\
(0.24)\end{array}$ & $\begin{array}{c}3566.84 \\
(1.75)\end{array}$ \\
\hline $\mathrm{R} 2$ & 0.16 & 0.26 & 0.2605 & 0.16 \\
\hline $\mathrm{F}$ & 25.58 & 165.59 & 227.62 & 24.79 \\
\hline Observations & 9131 & 1749 & 1749 & 9131 \\
\hline
\end{tabular}

$* \mathrm{p}<0.05 ; * * \mathrm{p}<0.01 ; * * * \mathrm{p}<0.001$

Soil texture

Coarse: sands, loamy sands and sandy loams with less than $18 \%$ clay and more than $65 \%$ sand.

Medium: sandy loams, loams, sandy clay loams, silt loams, silt, silty clay loams and clay loams with less than $35 \%$ clay and less than $65 \%$ sand. The sand fraction may be as high as $82 \%$ if a minimum of $18 \%$ clay is present.

Fine: clay, silty clays, sandy clays, clay loams, with more than $35 \%$ clay.

Soil slope (three slope classes)

Undulating: level to gently undulating, with generally less than $8 \%$ slope.

Hilly: rolling to hilly with slopes between $8 \%$ and $30 \%$.

Steep: steeply dissected to mountainous, with more than $30 \%$ slope. 
Table 4a: Seasonal and annual marginal effects, evaluated at the sample means for irrigated farms

Irrigated farms: Marginal temperature coefficients

(Net revenue $/{ }^{\circ} \mathrm{C}$ )

\begin{tabular}{|l|c|c|c|c|}
\hline Season & Coefficient & T-stat & \multicolumn{2}{|c|}{$\begin{array}{r}\text { 95\% Confidence intervals } \\
\text { (Lower, Upper) }\end{array}$} \\
\hline Winter temperature & 173.8 & 2.00 & 3.1 & 344.5 \\
\hline Spring temperature & -198.3 & -1.98 & -395.3 & -1.4 \\
\hline Summer temperature & 308.7 & 3.13 & 115.5 & 502.0 \\
\hline Fall temperature & -266.8 & -2.37 & -487.3 & -46.4 \\
\hline Annual temperature & 17.3 & 1.05 & -15.0 & 49.8 \\
\hline
\end{tabular}

Irrigated farms: Marginal precipitation coefficients

(Net revenue/mm/mo)

\begin{tabular}{|l|c|c|c|c|}
\hline Season & Coefficient & T-stat & \multicolumn{2}{|c|}{$\begin{array}{c}\text { 95\% Confidence intervals } \\
\text { (Lower, Upper) }\end{array}$} \\
\hline Winter precipitation & 12.3 & 2.28 & 1.7 & 22.8 \\
\hline Spring precipitation & -12.3 & -2.85 & -20.7 & -3.8 \\
\hline Summer precipitation & 12.9 & 3.86 & 6.3 & 19.4 \\
\hline Fall precipitation & -13.1 & -3.84 & -19.7 & -6.4 \\
\hline Annual precipitation & -0.2 & 0.96 & -9.9 & 9.4 \\
\hline
\end{tabular}


Table 4b: Seasonal and annual marginal effects, evaluated at the sample means for dryland farms

Dryland farms: Marginal temperature effects

(Net revenue $/{ }^{\circ} \mathrm{C}$ )

\begin{tabular}{|l|l|l|l|l|}
\hline Season & Coefficient & T-stat & \multicolumn{2}{|c|}{$\begin{array}{r}\text { 95\% Confidence intervals } \\
\text { (Lower, Upper) }\end{array}$} \\
\hline Winter temperature & 70.9 & 6.17 & 48.4 & 93.4 \\
\hline Spring temperature & -111.5 & -8.70 & -136.6 & -86.3 \\
\hline Summer temperature & 76.3 & 6.89 & 54.6 & 98.1 \\
\hline Fall temperature & -47.1 & -3.99 & -70.2 & -24.0 \\
\hline Annual temperature & -11.3 & -3.97 & -16.9 & -5.7 \\
\hline
\end{tabular}

Dryland farms: Marginal precipitation effects

Net revenue/mm/mo

\begin{tabular}{|l|c|c|c|c|}
\hline Season & Coefficient & T-stat & \multicolumn{2}{|c|}{$\begin{array}{r}\text { 95\% Confidence intervals } \\
\text { (Lower, Upper) }\end{array}$} \\
\hline Winter precipitation & -2.88 & -3.29 & -4.59 & -1.16 \\
\hline Spring precipitation & 3.44 & 4.74 & 2.02 & 4.87 \\
\hline Summer precipitation & 0.84 & 3.29 & 0.34 & 1.35 \\
\hline Fall precipitation & 1.21 & 3.78 & 0.58 & 1.83 \\
\hline Annual precipitation & 2.62 & 5.58 & 1.70 & 3.54 \\
\hline
\end{tabular}

Table 5: Marginal annual climate impacts

\begin{tabular}{lcc}
\hline & Dryland & Irrigated \\
\hline Mean net revenue $(\mathrm{US} \$ / \mathrm{ha})$ & 325.7 & 1283.8 \\
Mean annual temperature $\left({ }^{\circ} \mathrm{C}\right)$ & 23.2 & 19.6 \\
Mean annual precipitation $(\mathrm{mm} / \mathrm{mo})$ & 34.4 & 71.6 \\
Marginal temperature effect $\left(\$ / \mathrm{ha} /{ }^{\circ} \mathrm{C}\right)$ & -11.34 & 17.37 \\
Marginal precipitation effect $(\$ / \mathrm{ha} / \mathrm{mm} / \mathrm{mo})$ & 2.62 & -0.22 \\
Annual temperature elasticity & $-0.81^{*}$ & 0.31 \\
Annual precipitation elasticity & $0.28^{*}$ & -0.01 \\
\hline
\end{tabular}

* significant at $5 \%$

Note: Marginal effects and elasticities are evaluated at the mean climate of the dryland and irrigated sample. 
Table 6: Comparison of irrigation and welfare estimates for endogenous and exogenous models across different climate scenarios

\begin{tabular}{llcc}
\hline & $\begin{array}{l}\text { Climate } \\
\text { scenario }\end{array}$ & Endogenous approach & Exogenous approach \\
\hline \multirow{3}{*}{$\begin{array}{lll}\text { Mean probability of } \\
\text { irrigation }\end{array}$} & $5^{\circ} \mathrm{C} \Delta$ in $\mathrm{C}$ & 0.166 & \\
& $-20 \% \Delta$ in $\mathrm{P}$ & 0.171 & 0.162 \\
& $+20 \% \Delta$ in P & 0.157 & \\
\hline \multirow{3}{*}{$\Delta$ in welfare } & $2.5^{\circ} \mathrm{C} \Delta$ in T & 0.167 & $-12 \%$ \\
& $5^{\circ} \mathrm{C} \Delta$ in T & $-8 \%$ & $-21 \%$ \\
& $-20 \% \Delta$ in P & $-14 \%$ & $-16 \%$ \\
& $+20 \% \Delta$ in P & $-21 \%$ & $14 \%$ \\
\hline
\end{tabular}

Note: The current probability of irrigation is 0.162 . 

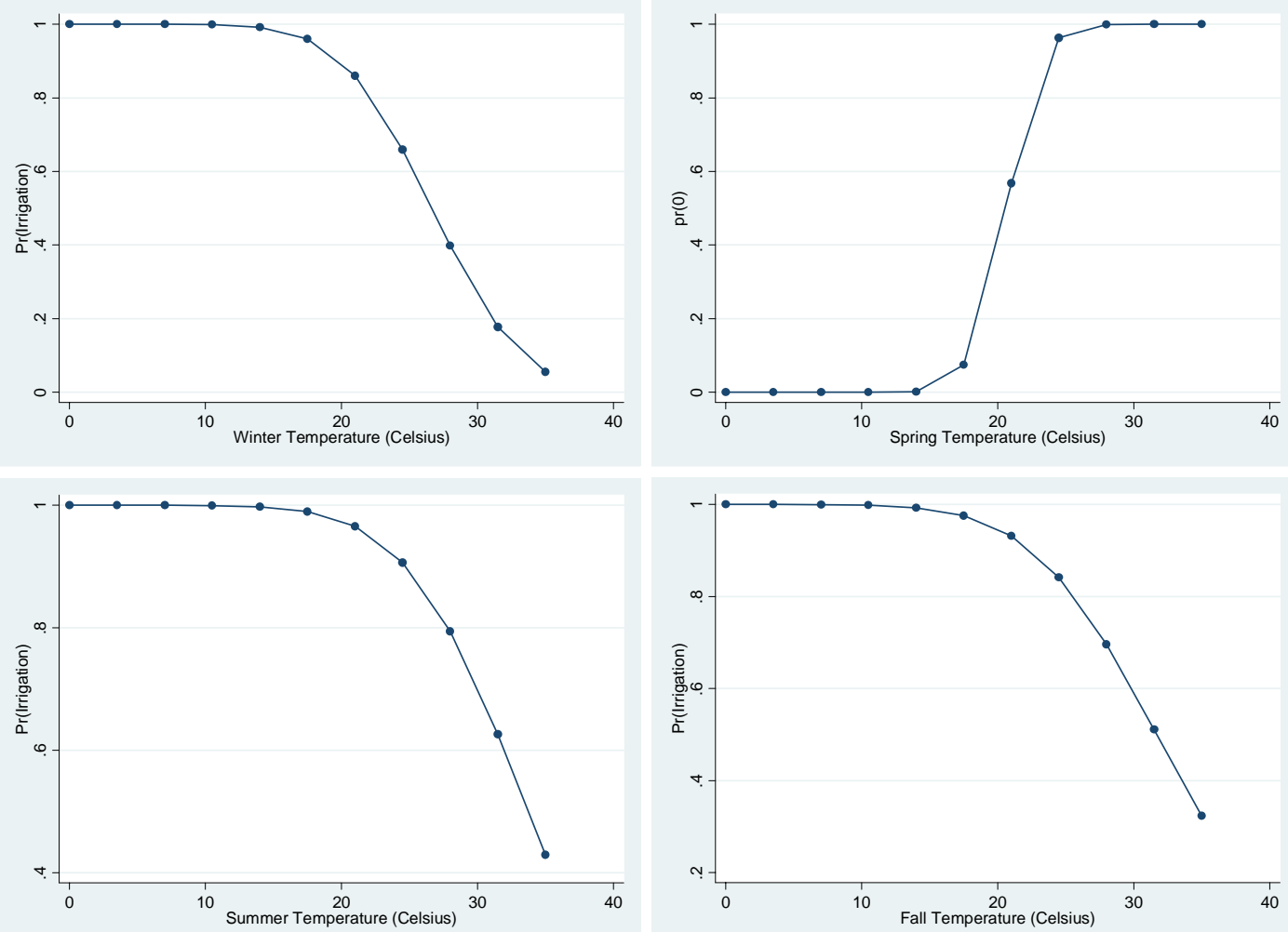

Figure 1a: Relationship between seasonal temperature and the probability of adopting irrigation

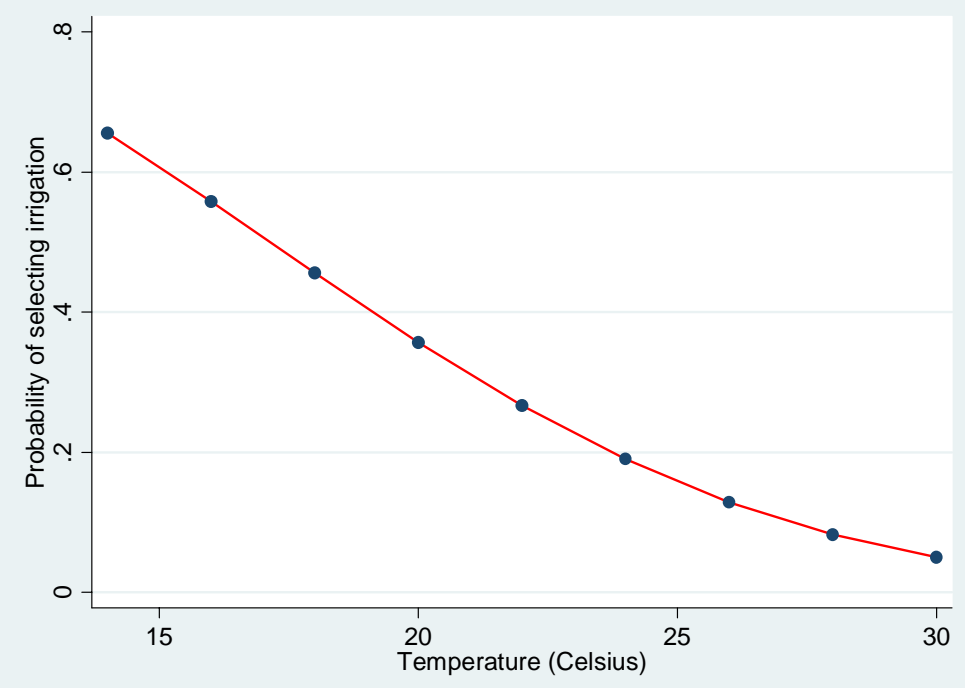

Figure 1b: Relationship between annual temperature and the probability of adopting irrigation 

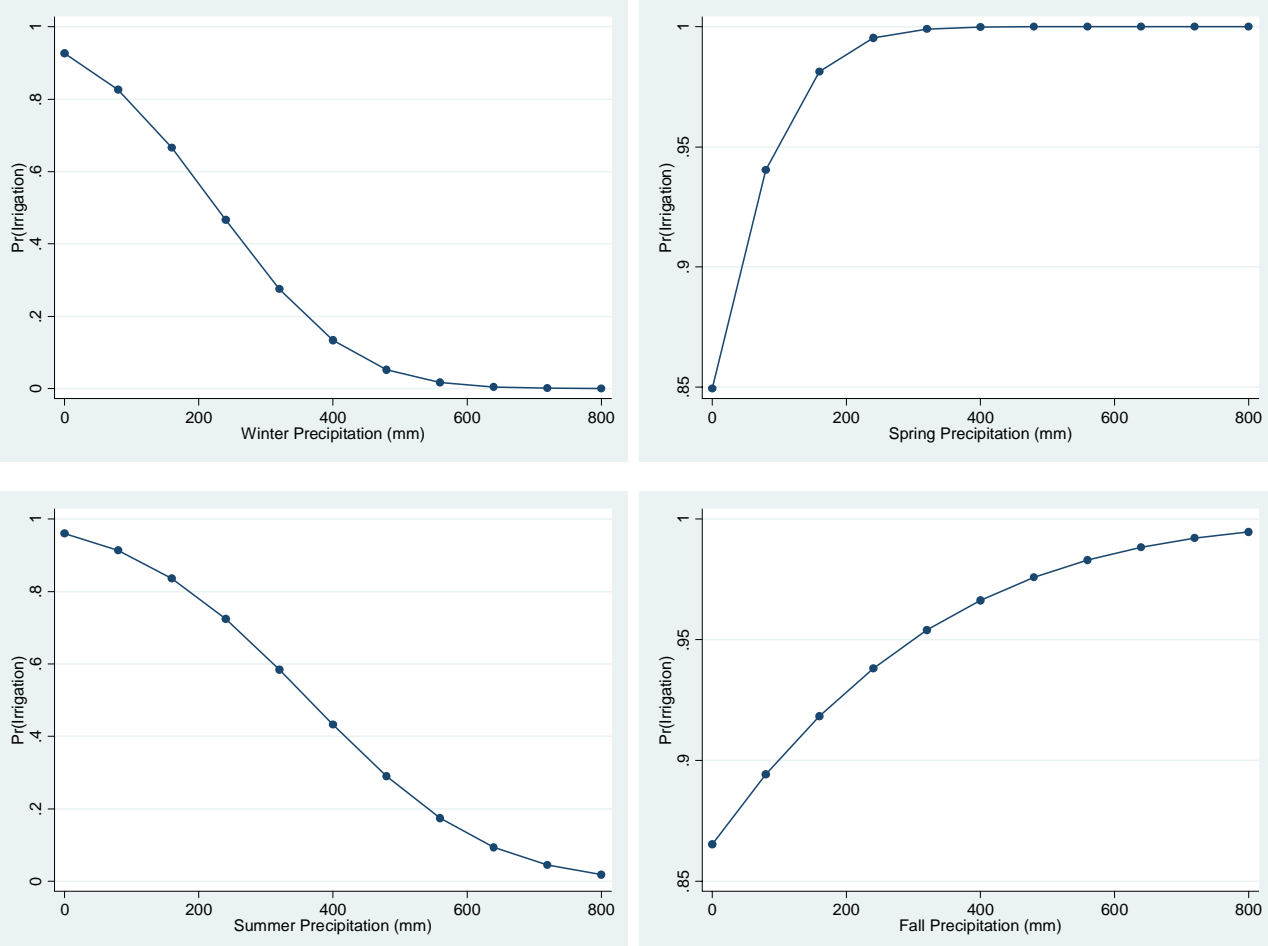

Figure 2a: Relationship between seasonal precipitation and the probability of adopting irrigation

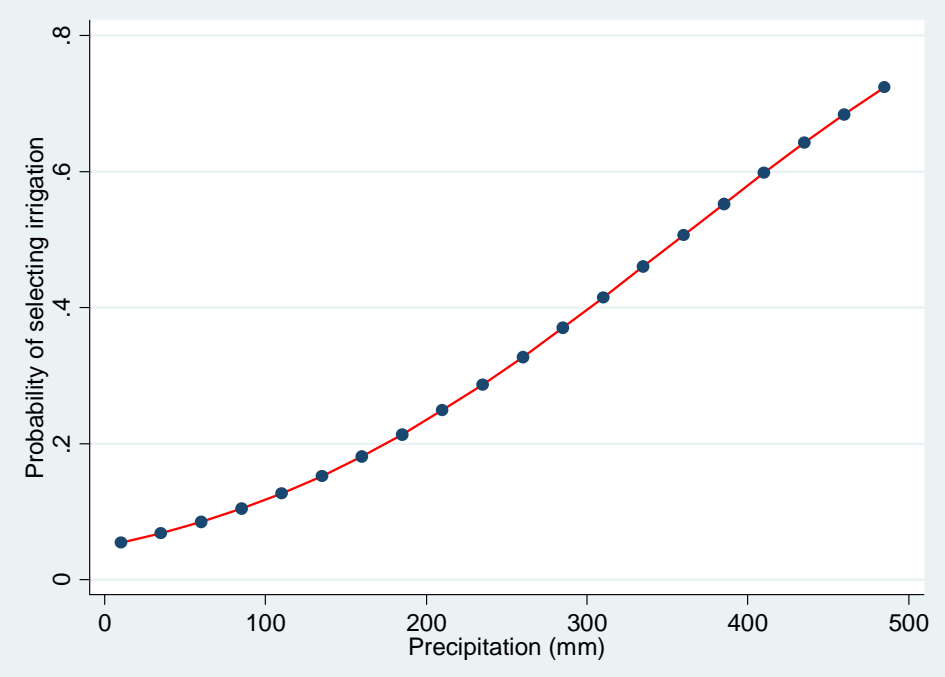

Figure 2b: Relationship between annual precipitation and the probability of adopting irrigation 


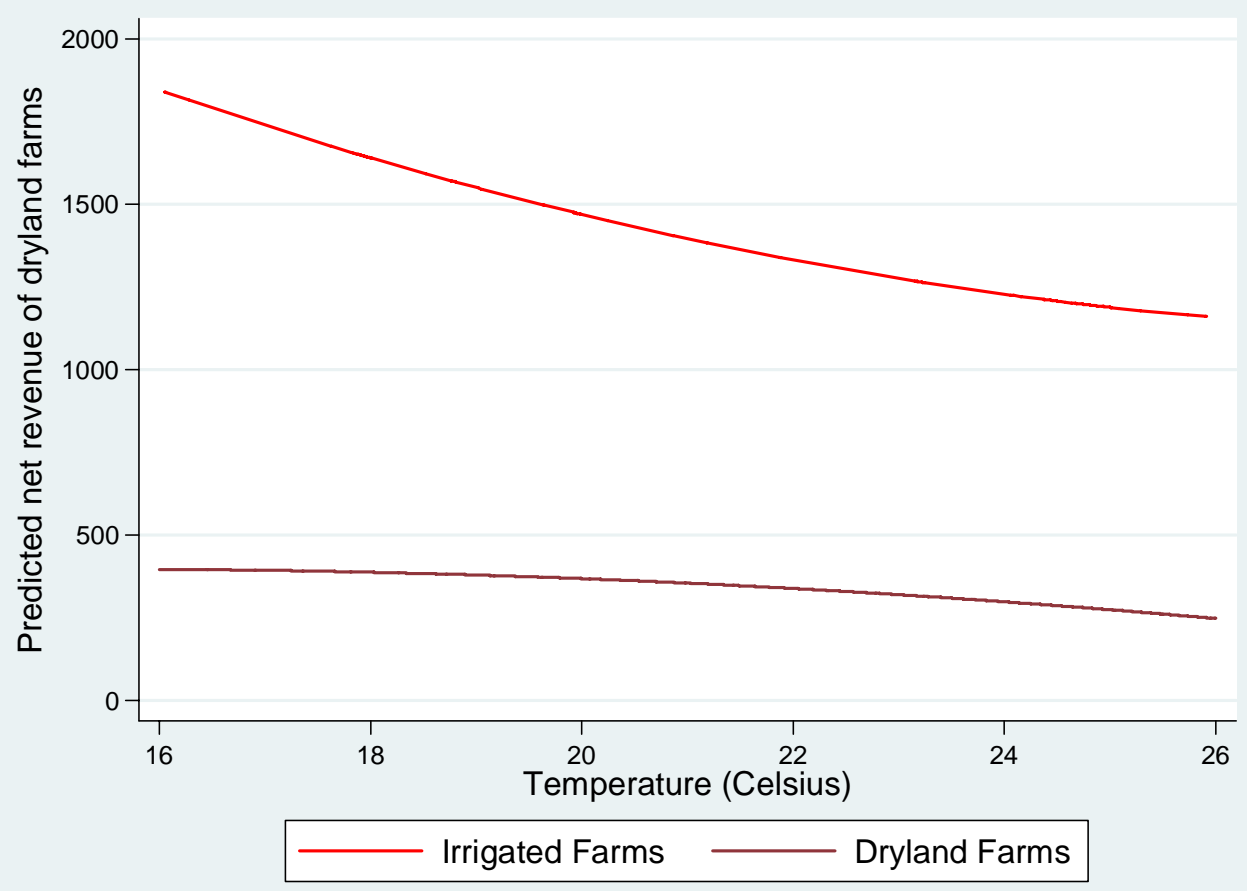

Figure 3: Temperature response functions of irrigated and dryland farms

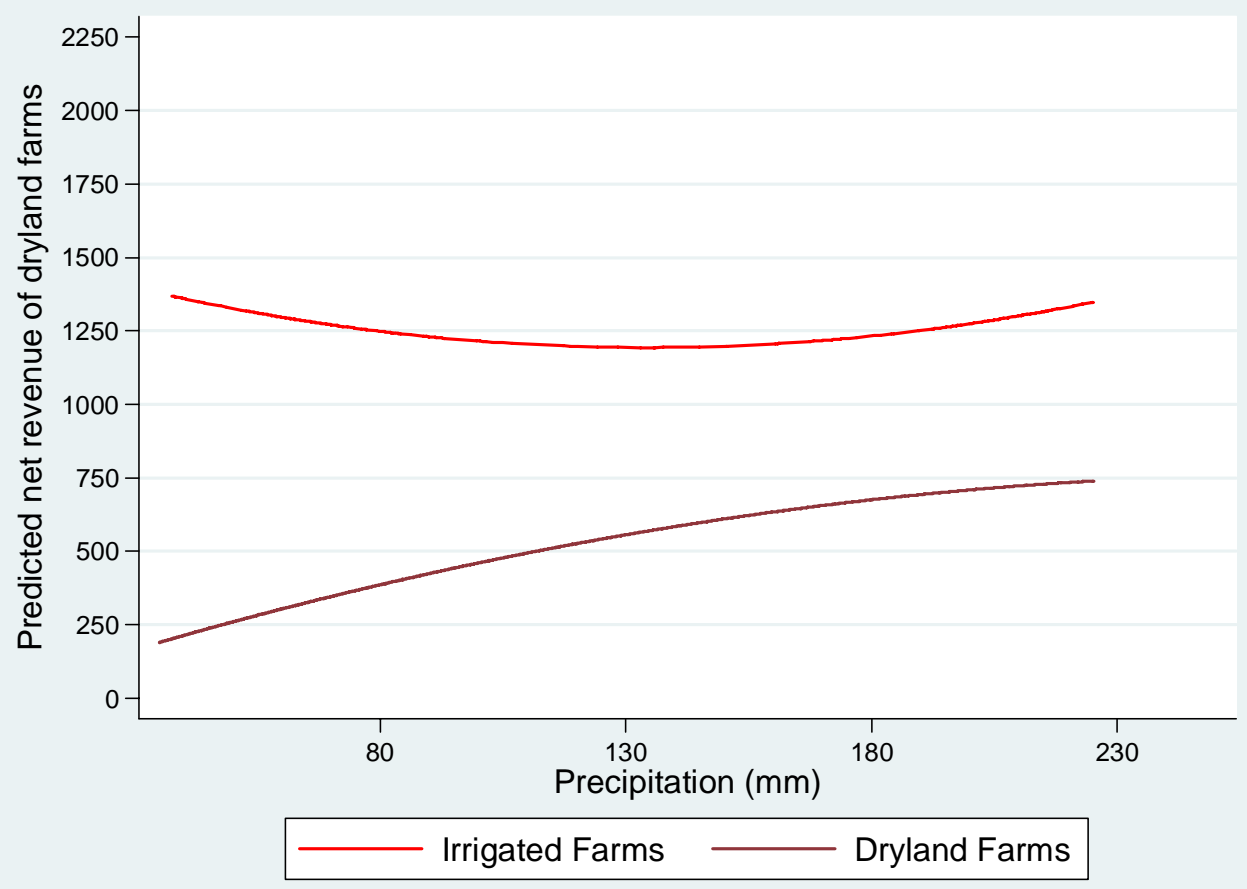

Figure 4: Precipitation response functions of irrigated and dryland farms 